\title{
Fertilization and oversowing on natural grassland: effects on pasture characteristics and yearling steers performance ${ }^{1}$
}

\section{Eduardo Tonet Ferreira ${ }^{2}$, Carlos Nabinger ${ }^{3}$, Denise Adelaide Gomes Elejalde ${ }^{2}$, Aline Kellermann de Freitas ${ }^{2}$, Igor Justin Carassai ${ }^{2}$, Fernanda Schmitt ${ }^{4}$}

\footnotetext{
1 Trabalho financiado pelo CNPq (Edital MCT/CNPq 15/2007) e Agropecuária Cantagalo.

2 Programa de Pós-graduação em Zootecnia, Universidade Federal do Rio Grande do Sul.

${ }^{3}$ Departamento de Plantas Forrageiras e Agrometeorologia, UFRGS

${ }^{4}$ Faculdade de Agronomia. Bolsista PIBIC/UFRGS.
}

\begin{abstract}
The objective of this study was to evaluate the vegetal and animal production of a natural pasture on a Mollisol soil in the region of Campanha, in RS. The experimental design consisted of complete randomized blocks with three replicates, which enables the comparison between natural unfertilized pastures with fertilized pastures and pastures fertilized and overseeded with Lolium multiflorum, Lotus corniculatus cv. São Gabriel and Trifolium repens cv. Lucero (NPO). Data were submitted to the analyses of variance considering seasons of the year as time repeated measurements. Aberddeen Angus calves of about nine months of age were used in continuous stocking with variable stocking rate in order to maintain forage offer at $13 \%$ of live weight. Data were collected between July 7th (2007) and May 3rd (2008), totaling 302 days. Fertilized and oversown pastures showed higher green forage mass mainly in the spring, as result of higher dry matter (DM) accumulation rate. Average daily live-weight gain for fertilized pasture $(0.581 \mathrm{~kg} / \mathrm{day})$ was higher than for natural pasture $(0.473 \mathrm{~kg} /$ day $)$. Higher live-weight gains were obtained in the fall $(0.869 \mathrm{~kg} / \mathrm{day})$. Stocking rate showed interaction with the seasons of the year, with higher stocking rates obtained in oversown pasture (701 kg of LW/ha) and fertilized pasture (667 kg of LW/ha) during the spring. Live-weight gain per hectare from natural pasture (224 kg LW/ha) was lower than on fertilized (310 kg LW/ha) and over-sown pasture (287 kg LW/ha). Forage mass, dry matter content, forage allowance and pasture height explained $61 \%$ of the average live weight gain. Despite the good performance of native grasslands in this region in its natural condition, the utilization of different inputs as fertilization and oversowing of winter cultivated species promoted positive differences in forage production and its distribution along the year and in animal yield
\end{abstract}

Key Words: daily live weight gain, forage accumulation rate, forage offer, seasonal forage production, stocking rate

\section{Introduction}

The rearing of beef cattle in complete cycle systems is a stage in the production process that cannot bring immediate financial return, like in the finishing phase. For this reason, many farmers end up leading this production phase inefficiently, making it too long and creating an undesirable herd structure that increases the production costs (Beretta et al., 2002). This is mainly due to feeding strategies that do not meet nutritional requirements of growing steers. In general, beef cattle production in the region of Campanha, in Rio Grande do Sul, is done in natural pastures, but these pastures are not homogeneous in terms of floristic composition, which is mainly dependent on soil condition and previous management practices. Their potential can only be properly assessed when forage allowance is controlled as recommended by Maraschin (2001). Moreover, it is known that usually during the fall-winter native pastures of southern Brazil have low forage accumulation rate due to the low proportion of cool season species (Nabinger et al., 2009). However, there is little information in the literature on this specific region and soil type.

The nutritional requirements of animals in the postweaning phase which, in this region, usually starts in the fall, is high and can only be met in systems fed exclusively on grazing, with pastures with high contribution of cool season species. In natural pastures, when the frequency of these species within pasture communities is sufficient, its contribution in the forage offered to animal can be increased by adequate intensity and frequency of defoliation, by deferment at the end of summer or even by fertilization (Nabinger et al., 2009). On the other hand, low frequencies of these species can be overcome by over-seeding winter forage species provided it is followed by the correction of soil fertility (Lobato \& Barcellos, 1992; Risso et al., 1998; Fontoura Junior et al., 2000; Gatiboni et al., 2000; Rizo et al, 2004).

The objectives of this experiment were to evaluate the performance of beef cattle for rearing and the productivity 
of natural grassland typical of deep black soil of the region of Campanha, in Rio Grande do Sul, in its natural condition or modified by fertilization and over-seeded with winter forage species, in addition to seeking relationships between the characteristics of the pasture and animal production.

\section{Material and Methods}

The experiment was conducted at Cantagalo Farm, located in the municipality of Quaraí, "Campanha" physiographic region of Rio Grande do Sul, Brazil, between February 2007 and May 2008. The soil is a Vertissolo Ebânico Órtico chernossólico (VE) (Mollisol) (Embrapa, 2006). Soil analysis from samples collected at 10-15 cm depth in February 2007 showed the following results: pH 5.5, $7.1 \%$ organic matter, phosphorus $5.8 \mathrm{mg} / \mathrm{dm}^{3}, 104 \mathrm{mg} / \mathrm{dm}^{3}$ potassium, $81.6 \%$ of base saturation and absence of aluminum.

The climate, according to Köeppen's classification, is mesothermal, subtropical, belonging to class Cfa 2 . The experimental period was characterized by extreme low temperatures during the winter and the spring (38 days of frost between May and September) and the predominance of temperatures above $35^{\circ} \mathrm{C}$ during the summer, when significant rainfall deficit was also recorded (Table 1).

Typical vegetation at this region and this type of soil is characterized by relatively uniform grasslands with high floristic richness. Floristic survey done in 2008 revealed vegetation composed predominantly by Andropogon lateralis and many species from other genera like Paspalum, Piptochaetium, Briza, Stipa, Eleocharis e Coelorachis. More frequent forage legumes were Trifolium polymorphum and Desmodium incanum.

Experimental area totalized 49 ha and was divided into three blocks according to predominant topography. In each block the following treatments were randomly distributed: natural pasture (Natural), fertilized natural pasture (Fertilized), and natural pasture fertilized and over-seeded with winter forage species (Improved). On 07/09/2007 Fertilized pasture and Improved pasture were broadcast sown with $200 \mathrm{~kg} / \mathrm{ha}$ of diamonium phosphate (18-45-00) and in September with $200 \mathrm{~kg} / \mathrm{ha}$ of urea (45-00-00). In April 2008, $100 \mathrm{~kg} / \mathrm{ha}$ of diamonium phosphate were applied, totaling $144 \mathrm{~kg} / \mathrm{ha}$ of $\mathrm{N}$ and $135 \mathrm{~kg} / \mathrm{ha}$ of $\mathrm{P}_{2} \mathrm{O}_{5}$ for both treatments. Seeding of winter species was done in rows on the same date of the first fertilizer application. Species used were ryegrass (Lolium multiflorum), birdsfoot trefoil (Lotus corniculatus cv. São Gabriel) and white clover (Trifolium repens $\mathrm{cv}$. Lucero), with seeding rates of $30 \mathrm{~kg} / \mathrm{ha}, 8 \mathrm{~kg} / \mathrm{ha}$ and $3 \mathrm{~kg} / \mathrm{ha}$, respectively. In 2008, only ryegrass seeds were broadcast (20 kg/ha). All paddocks were previously mowed (from February 23 to March 6, 2007). After initial sowing and fertilizer application, all experimental units remained sealed until 07/07/2007 (the start of grazing), totaling a deferred period of 89 days, seeking the proper establishment of sown species. In order to prevent the flowering of Andropogon lateralis, main constituent of the upper stratum of the sward, and provide a better pasture structure in subsequent seasons, all plots were cut again between the $15^{\text {th }}$ and $27^{\text {th }}$ of February 2008.

Animals remained under continuous stocking with variable stocking rate to maintain forage on offer around $13 \mathrm{~kg} \mathrm{DM} / 100 \mathrm{~kg}$ of body weight, as recommended by Maraschin (2001). Four calves per experimental unit were used as testers and a variable number as regulators, according to Mott \& Lucas (1952). Animals were Aberdeen Angus castrated (pure breed), with an average age of nine months and average weight of $233 \mathrm{~kg}$. They were weighed monthly, after a fasting period of twelve hours. The average daily body weight gain (kg/day) was calculated as the difference between

Table 1 - Average of minimal and maximal monthly temperatures and decennials rainfall occurred during experimental period

\begin{tabular}{|c|c|c|c|c|c|}
\hline & \multicolumn{2}{|c|}{ Temperature } & \multicolumn{3}{|c|}{ Rainfall } \\
\hline & Minimal & Maximal & $1^{\text {st }}$ decennia & $2^{\text {nd }}$ decennia & $3^{\text {rd }}$ decennia \\
\hline & & & Year 2007 & & \\
\hline August & 7.0 & 22.6 & 25 & 70 & 0 \\
\hline September & 13.0 & 30.6 & 23 & 37 & 40 \\
\hline October & 14.4 & 30.8 & 67 & 55 & 98 \\
\hline November & 15.0 & 30.7 & 10 & 35 & 5 \\
\hline December & & & Year 2008 & & \\
\hline January & 19.3 & 35.0 & 29 & 0 & 13 \\
\hline February & 19.9 & 36.5 & 12 & 0 & 164 \\
\hline March & 19.3 & 40.4 & 110 & 0 & 20 \\
\hline April & 15.6 & 36.6 & 20 & 40 & 108 \\
\hline May & 15.6 & 36.6 & 0 & 95 & 0 \\
\hline
\end{tabular}


initial and final body weights of tester animals, divided by the number of days between weightings. Average stocking rate ( $\mathrm{kg} / \mathrm{ha}$ of live weight) was calculated for each experimental unit, by adding the weight of the testers, the weight of each regulator multiplied by the number of days each animal remained in the pasture, divided by the number of grazing days. For the calculation of live weight gain per area $(\mathrm{kg} / \mathrm{ha}$ of live weight), the stocking rate was divided by the average live weight of test animals, multiplied by the average daily gain and divided by the area of the experimental unit.

Forage mass was assessed monthly by double sampling technique (Haydock \& Shaw, 1975). At each assessment, 54 visual estimates of available forage were performed in frames of $0.25 \mathrm{~m}^{2}$. In each frame all vegetation above the litter was cut and weighed to establish a relationship between the visual estimate and the actual mass. The linear regressions generated were used for calibration of visual estimates later when estimating forage mass of each experimental unit. For these estimates, 50 visual assessments were done for each experimental unit also with squares of $0.25 \mathrm{~m}^{2}$. In these same squares, the height of canopy was measured with a graduated rule from de soil level up to the maximum level of the green leaves.

Forage accumulating rate (AR) was estimated according to Klingman et al. (1943), by using three exclusion cages per experimental unit. The amount of dry matter obtained from inside the cage, subtracted from the dry matter of the sample out of the cage in the previous evaluation, divided by the number of days between samplings provided the accumulation rate in $\mathrm{kg} / \mathrm{ha} / \mathrm{day}$. The sum of all rates of forage accumulation was the total production of dry matter of the evaluation period.

Samples from forage cut in the field were oven-dried $\left(65^{\circ} \mathrm{C}\right)$ to determine their dry matter content (DM\%) by percentage difference between the weight of green forage and its dry weight. Green forage mass (GHM, kg/ha) resulted from multiplying the total dry forage mass by the percentage of green material (\% MV) calculated from the manual separation of all samples cut out of the cage. Green material was measured as the sum of legumes and grasses/ juncaceous/sedges.

Stocking rate was adjusted every 28 days according to intended forage allowance (HA) of $13 \%$ of live weight by using the formula $\mathrm{SR}=(\mathrm{HM} / \mathrm{n}+\mathrm{PAR}) \times 100 / \mathrm{HA}$, where $\mathrm{SR}=$ stocking rate ( $\mathrm{kg} / \mathrm{ha}$ of live weight), $\mathrm{HM}=$ forage mass ( $\mathrm{kg} / \mathrm{ha}$ of forage dry matter), $\mathrm{n}=$ number of days between samplings (days), $\mathrm{PAR}=$ projected rate of daily accumulation of dry matter (kg/ha/day), HA = forage allowance (kg DM/ $100 \mathrm{~kg}$ of live weight/day). Actual forage allowance was calculated later by replacing the projected values of forage accumulation rate by the measured values and the average stocking rate between the evaluation period in the formulae above.

Data were analyzed as a randomized complete block design by using the MIXED procedure of SAS statistical software (Little et al., 1996), specifically for cases of repeated measures in time. Data were grouped into four periods, corresponding roughly to the four seasons: winter (07/07/2007 to $09 / 10 / 2007)$, spring (09/10/2007 to $12 / 13 / 2007)$, summer (12/13/2007 to 8/03/2008) and fall (03/08/2008 to 05/03/2008). The means of monthly observations of each season (two in the winter, three in the spring, three in the summer and two in the fall) were subjected to analysis of variance and compared by Tukey test at $5 \%$.

The general model regarding the analysis of the variables studied was represented by: $Y i k j=\mu+\mathrm{Ti}+\mathrm{Bj}+\mathrm{Eij}+\mathrm{Pk}+\mathrm{TPik}$, where: $Y i k j=$ dependent variables, $\mu=$ mean of all observations, $\mathrm{Bj}=$ effect of block $\mathrm{i} ; \mathrm{Ti}=$ effect of treatment $\mathrm{i}, \mathrm{Pk}=$ effect of period $\mathrm{k}$; TPik $=$ interaction treatment $\mathrm{i} \times$ period $\mathrm{k}$; Eij $=$ random error associated with each $\mathrm{j}$ observation.

SAS's stepwise multiple regression procedure was used to evaluate the correlation coefficients between ADG and sward variables. The characteristics of the pasture used to compose the model were: forage yield, green forage mass, forage mass of legumes, dry matter content, dead material content, forage mass of undesirable species, forage accumulation rate and height of canopy.

\section{Results and Discussion}

Forage allowance did not differ between treatments: Natural, Fertilized or Improved pastures. The similar forage offer maintained in these different conditions (13\%), ensures the absence of possible confusing effect due to this factor. However, there was variation in these parameters according to seasons, with values of 12.5, 14.5, 13.9 and $11.5 \%$ of live weight in winter, spring, summer and fall, respectively, with this last value significantly different from the others. In spite of this variation, all values were at levels that allow maximum gains per animal in native pastures, between 11.5 and $13.5 \%$ of live weight (Maraschin, 2001; Moojen \& Maraschin, 2002). Values above those observed in this study may provide a small decrease in production per hectare due to the lower stocking rate. These variations in the values of forage allowance were due to underestimates in the previsions of forage accumulation rate, which affected the calculation of stocking rate. This underestimation was the result of some hitherto existing knowledge about this type of natural environment. 
The forage accumulation rate, with the exception of the summer, showed increased response to the application of inputs. The effect of fertilization was significant in the winter and spring but had no effect during the summer and fall (Figure 1).

These results corroborate those obtained by Gatiboni et al. (2000) and Berreta (2001) on natural pastures fertilized and over-seeded with winter cultivated species in the Central Depression of Rio Grande do Sul and Uruguay, respectively. Naturally, the magnitude of responses obtained by these authors in comparison with this work is different. This is due to different environmental conditions (climate and soil), type of vegetation, management of defoliation, timing and rates of fertilizer applications. The effects of timing and quantity of fertilizers to be applied, as well as the management of grazing (changes in forage offer and deferment periods), still need to be studied in this type of natural grassland

Even without fertilization, Aguinaga (2004) and Soares et al. (2005) achieved substantial increases in the accumulation rate of natural grassland of the Central Depression of RS just by changing the forage allowance in the spring from $12 \%$ to $8 \%$ of live weight. This alternative management of defoliation, not applied in the present study, may be even more important in pastures fertilized and overseeded with ryegrass because this later species and the native tussock winter species, favored by fertilization, can exert an important competition on summer native species that are starting growth in the spring.

Nevertheless, the results of this study show the potential for response to application of inputs in this type of pasture. In the winter, the net rate of accumulation was negative on natural grassland (senescence rate greater than growth rate) and positive in fertilized treatments. In the spring, the

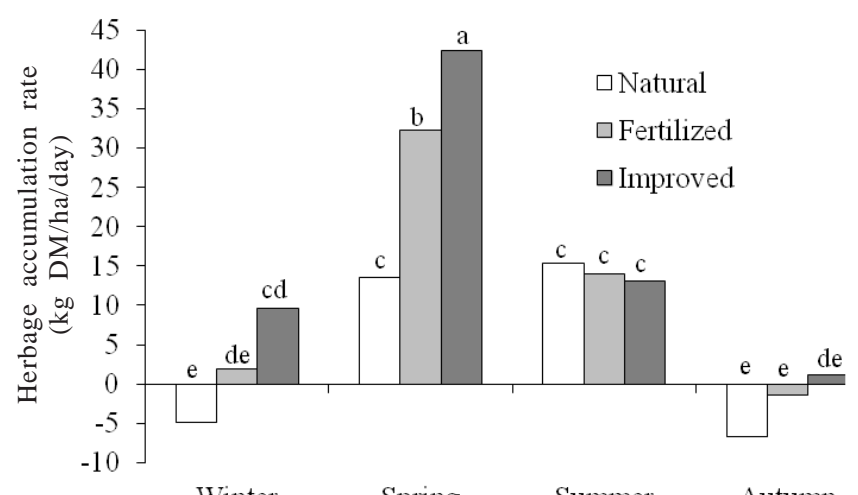

Values followed by same letters are not different as indicated by Tukey test $(\mathrm{P}<0.05)$

Figure 1 - Forage accumulation rate in different seasons in natural, fertilized and improved pastures. fertilized and improved natural pastures allowed increases of $130 \%$ and $200 \%$ of net forage production, respectively, compared with natural grassland. In the summer there was no difference between treatments as consequence of low rainfall (Table 1). In the fall, the net forage accumulation rate was negative for the natural pasture, almost zero for the fertilized pasture and slightly positive for the improved pasture. At that time the C3 species native and cultivated in early growing season started to replace the growth of $\mathrm{C} 4$ species, and fertilization contributes to improving their contribution in forage accumulation. The total forage mass was significantly higher in the fertilized pasture in comparison with natural grass and improved pasture, which did not differ (Table 2).

This greater forage mass in fertilized conditions was due to the response to nitrogen fertilizer in the spring, when there was an underestimation of the accumulation rate for all treatments. However, the magnitude of the underestimation was greater for the fertilized pasture, thus causing an increase in residual forage mass in this condition. According to Moojen \& Maraschin (2002), the maintenance of a forage mass between $1476-1765 \mathrm{~kg} \mathrm{DM} / \mathrm{ha} /$ day corresponds to the range that allows the expression of the potential of both forage and livestock production. Similar data are presented by Aguinaga (2004), who found higher primary and secondary productivities with average mass of $1.475 \mathrm{~kg}$ of forage DM/ha. Therefore, during the average period of evaluation, forage mass of Natural and Improved pasture were maintained within the optimum range indicated by these authors, while forage mass in the fertilized pasture was maintained above. One must consider that the results found by these authors cited above were obtained on ultisol in the Central Depression of Rio Grande do Sul, and there are no results for the soil type and climatic region where this study was carried out. Therefore, it is not possible to assert whether any of the observed forage mass values on the different treatments were limiting animal performances or not.

Regardless of the condition of pasture, total forage mass remained constant until the end of the summer and decreased significantly only in the fall (Table 3).

Table 2 - Effect of the condition of natural pasture on total forage mass, canopy height and forage dry matter content

\begin{tabular}{lccc}
\hline Parameter & \multicolumn{3}{c}{ Pasture condition } \\
\cline { 2 - 4 } & Natural & Fertilized & Improved \\
\hline Total forage mass (kg/ha DM) & $1773 \mathrm{~b}$ & $2009 \mathrm{a}$ & $1748 \mathrm{~b}$ \\
Canopy height (cm) & $9.7 \mathrm{~b}$ & $11.7 \mathrm{a}$ & $10.5 \mathrm{~b}$ \\
Dry matter content (\%) & $44 \mathrm{a}$ & $39 \mathrm{~b}$ & $41 \mathrm{ab}$ \\
\hline
\end{tabular}

Means followed by different letters in the row differ significantly $(\mathrm{P}<0.05)$ by Tukey test 
Table 3 - Effect of seasons on total forage mass, canopy height and forage dry matter content

\begin{tabular}{lcccc}
\hline Variable & \multicolumn{4}{c}{ Season } \\
\cline { 2 - 5 } & Winter & Spring & Summer & Autumn \\
\hline $\begin{array}{l}\text { Total forage mass } \\
\text { (kg/ha of DM) }\end{array}$ & $2175 \mathrm{a}$ & $1982 \mathrm{a}$ & $1968 \mathrm{a}$ & $1249 \mathrm{~b}$ \\
$\begin{array}{l}\text { Canopy height }(\mathrm{cm}) \\
\text { Dry matter content }(\%)\end{array}$ & $10.4 \mathrm{~b}$ & $13.6 \mathrm{a}$ & $10.3 \mathrm{~b}$ & $8.2 \mathrm{c}$ \\
$\begin{array}{l}\text { Means followed by different letters in the row differ significantly }(\mathrm{P}<0.05) \text { by } \\
\text { Tukey test. }\end{array}$
\end{tabular}

Relatively high forage mass values found in the winter were the result of initially greater forage availability caused by the deferment to which the entire experimental area was subjected during the establishment of the species overseeded. The significant decrease in forage mass in the fall was due to low accumulation rate in this season, still because of the rainfall deficit at the end of summer and the decrease in solar radiation and temperature. Similar effects on native fertilized pasture were also observed by Carassai et al. (2008). The mowing held in late February also contributed to this low mass, which eliminated part of the upper stratum.

Canopy height is an important structural feature to explain animal performance. According to Carvalho (1997), harvesting capacity, intake rate, bite weight, biting rate, bite depth and grazing time variables are highly related to sward height and largely determine the animal intake and performance. The fertilized pasture showed greater sward height (Table 2) as a consequence of the maintenance of higher residual forage mass. The average heights were also affected by the seasons (Table 3). In the spring heights were higher, possibly a result of the growth stage of the winter species that start flowering at the end of this season. The decrease during the fall was due to the lower residual forage mass observed at that season. Neverheless, for all the conditions of the pastures, regardless of season, height values remained close to those proposed by Gonçalves et al. (2009). These authors found that higher intake rate of cattle in natural pasture occurred with pasture height of $11.4 \mathrm{~cm}$ and proposed target management close to this value.

Sward height showed good correlation with forage mass, showing that its control via adjustment of stocking rate as function of forage allowance can be a tool to provide sward structures more adequate for high animal performances. Pearson's coefficient between forage mass and sward height was 0.68 ( $\mathrm{P}<0.001)$, quite close to the value of 0.70 presented by Santos et al. (2008). On average of all the pastures conditions, the relationship between forage mass and sward height assumed a quadratic behavior (TFM $=643.28 \mathrm{SH}$ $24.01 \mathrm{SH}^{2}$ - 213.59) with a determination coefficient of 0.64 $(\mathrm{P}<0.001)$. Similarly to the total mass of forage, the green forage mass also showed significant correlation with height $(\mathrm{r}=0.83, \mathrm{P}<0.01)$. On average, adding one $\mathrm{cm}$ in the sward high corresponded to an increase of $105.51 \mathrm{~kg} / \mathrm{ha}$ of green dry matter forage $\left(\mathrm{r}^{2}=0.69, \mathrm{P}<0.001\right)$.

Probably, the best variable for explaining the response of native pasture to the treatments applied and to seasonal variations is the green forage mass. This feature has been affected by the interaction between the condition of pasture and seasons (Table 4).

Fertilization or fertilization + over-seeding enabled maintenance of a bigger proportion of green forage within the sward than in natural conditions, especially in the spring. This interaction results from the fact that the nitrogen fertilizer applied at the beginning of this season provided greater contribution of green leaves due to their longer lifespan, contributing to higher green plant biomass (Mazzanti et al., 1994). In the improved pasture, the introduction of cultivated species of C3 metabolic pathway also contributes to greater presence of green material. In addition, the spring season, through good soil moisture and temperatures near the optimum for these species, provides conditions for plants to better express their productive potential (Nabinger, 1998). The green forage mass may also be partially explained by dry matter content of forage, which was affected by treatments (Table 2) and by season (Table 3 ). The improved and fertilized pastures showed lower values for this feature and the summer was the period that showed highest levels. One reason for this increase is due to the contribution of dead material in the pasture. During the summer, on average for the three treatments, $54 \%$ of the total forage consisted of dead material, while in the spring, these values were $35 \%(\mathrm{P}<0.001)$. The low rainfall associated with high temperatures between December and February (Table 1) increased leaf senescence as consequence of water deficit. As stated by Nabinger (1998), in situations of moderate water stress, leaves reduce photosynthetic capacity and reallocate the assimilates to the root system, leading to a decrease in leaf growth rate and the aging of the pasture, since the rate of emergence of new leaves and its leaf

Table 4 - Average mass of green forage (kg/ha of DM) as function of pasture conditions and season of the year

\begin{tabular}{lcccc}
\hline Season & \multicolumn{4}{c}{ Pasture } \\
\cline { 2 - 5 } & Natural & Fertilized & Improved & Means \\
\hline Winter & $1000 \mathrm{bc}$ & $1103 \mathrm{abc}$ & $1089 \mathrm{bc}$ & 1064 \\
Spring & $909 \mathrm{bcd}$ & $1302 \mathrm{ab}$ & $1512 \mathrm{a}$ & 1241 \\
Summer & $812 \mathrm{cde}$ & $1008 \mathrm{bc}$ & $871 \mathrm{cde}$ & 897 \\
Autumn & $540 \mathrm{de}$ & $741 \mathrm{cde}$ & $492 \mathrm{e}$ & 591 \\
Means & 815 & 1039 & 991 & \\
\hline Means followed by different letters are significantly & & & \\
test.
\end{tabular}

R. Bras. Zootec., v.40, n.9, p.2039-2047, 2011 
lifespan decline. The contribution of dead material also differed between treatments: 52, 45 and $42 \%$ in the natural, fertilized and improved pastures, respectively $(\mathrm{P}<0.05)$. Likewise, Carassai et al. (2008) observed in natural grassland content of $62.5 \%$ of dead material from January to March, as a result of drought.

Total production of dry matter during the experimental period, resulting from the sum of the forage accumulation rates, was significantly $(\mathrm{P}<0.05)$ different among all treatments, with values of 2995, 4607 and $5943 \mathrm{~kg} / \mathrm{ha} \mathrm{DM}$ for 302 days of grazing for Natural, Fertilized and Improved pastures, respectively. Values for Natural pasture are close to those of Soares et al. (2005), who verified the production of $2953 \mathrm{~kg} \mathrm{DM} / \mathrm{ha} /$ year in native pasture at Central Depression of Rio Grande do Sul. In a native grassland fertilized and overseeded with winter cultivated species, Rizo et al. (2004) reported year round production of $5016 \mathrm{~kg} \mathrm{DM} / \mathrm{ha}$, close to the value obtained in the present study in 302 days.

Concerning the variables related to animal performance and productivity per hectare, only stocking rate was significantly affected by the interaction between treatments and grazing season (Table 5).

During the winter and the fall, stocking rates were similar in natural, fertilized and improved pastures. The lack of response in the winter resulted from the large amount of forage accumulated in the deferral period before the entry of animals and which was similar in the different pasture treatments. In the fall of following year, the lack of response could be attributed to the lower residual mass resulting from the low rate of forage accumulation and the mowing, which homogenized the different treatments done to the pastures. In the spring and summer, the stocking rates of the fertilized and improved pastures were significantly higher than those observed in the natural pasture. This is due to the increased growth rate in the treatments that received inputs (Figure 1). In a similar study, Fontoura Júnior et al. (2000) quantified stocking rates of 369 and $501 \mathrm{~kg} / \mathrm{ha}$ for natural and fertilized + overseeded pastures, respectively. The most important

Table 5 - Effect of interaction between the condition of pasture and season of the year on the stocking rate $(\mathrm{kg} / \mathrm{ha}$ of live weight)

\begin{tabular}{lcccc}
\hline Season & \multicolumn{4}{c}{ Pasture condition } \\
\cline { 2 - 5 } & Natural & Fertilized & Improved & Means \\
\hline Winter & $530 \mathrm{c}$ & $569 \mathrm{bc}$ & $556 \mathrm{bc}$ & 551 \\
Spring & $517 \mathrm{~cd}$ & $667 \mathrm{a}$ & $701 \mathrm{a}$ & 628 \\
Summer & $454 \mathrm{~d}$ & $603 \mathrm{~b}$ & $662 \mathrm{a}$ & 573 \\
Autumn & $366 \mathrm{e}$ & $370 \mathrm{e}$ & $376 \mathrm{e}$ & 371 \\
Means & 466 & 552 & 574 & \\
\hline
\end{tabular}

Means followed by different letters are significantly different $(\mathrm{P}<0.05)$ by Tukey test. stocking rate in the present experiment is probably due to nitrogen fertilization in the spring, which was not used in the cited study, and also by intrinsic characteristics of the vegetation itself. In fact, this is the first evaluation performed in this type of natural grassland with controlled forage offer, and it also demonstrates a high capacity of these pastures, even in their natural condition.

In terms of stocking density, the lowest values were observed in the natural pasture during the fall ( $0.81 \mathrm{AU} / \mathrm{ha})$ with an average of $1.03 \mathrm{AU} /$ ha for the whole experimental period. With fertilization, these values increase to 1.23 and 1.27 AU/ha in fertilized and improved pastures, respectively. Also, in natural rangelands of the region of Campanha, in Rio Grande do Sul, Pötter \& Lobato (2004) suggest lower stocking rates ( $0.5 \mathrm{AU} / \mathrm{ha}$ ), however, to handle primiparous heifers, which reveals the importance of knowing the animal category to establish criteria for setting the stocking rate.

Live weight production per unit area reflected the simple effect of both condition of the pasture and season, whereas the average daily gain was affected only by the season (Table 6).

The average daily gain of animals was not significantly affected by the treatment $(0.473,0.581$ and $0.492 \mathrm{~kg} / \mathrm{animal} / \mathrm{day}$ for natural, fertilized and improved natural pasture, respectively). This result is surprising because, in the light of many studies carried out on native pastures in other regions of the state, greater individual gains in improved pasture would be expected. Fontoura Júnior et al. (2000) quantified annual average daily gains of 0.250 and $0.640 \mathrm{~kg} /$ day for animals grazing native pasture and native pasture fertilized and over-seeded with winter species, respectively. Lobato \& Barcellos (1992) also showed better animal response in improved natural pastures compared to natural pasture without inputs. Our results indicate that in the region under study, the floristic composition of the natural pastures, which includes a good balance between species of different metabolic pathways an balanced forage distribution throughout the year, enabled average annual gain of $0.473 \mathrm{~kg} / \mathrm{animal} /$ day, values close the average daily gain obtained by adding inputs such as fertilizers to the natural pasture or utilizing cultivated species.

Table 6 - Effect of the seasons on daily live weight gain and animal production per area

\begin{tabular}{lcc}
\hline Season & $\begin{array}{c}\text { Average daily gain } \\
(\mathrm{kg} / \text { animal/day })\end{array}$ & $\begin{array}{c}\text { Gain per area } \\
(\mathrm{kg} \mathrm{LW} / \mathrm{ha})\end{array}$ \\
\hline Winter & $0.499 \mathrm{~b}$ & $77.1 \mathrm{~b}$ \\
Spring & $0.533 \mathrm{~b}$ & $113.8 \mathrm{a}$ \\
Summer & $0.160 \mathrm{c}$ & $30.5 \mathrm{~d}$ \\
Autumn & $0.869 \mathrm{a}$ & $52.5 \mathrm{c}$ \\
\hline
\end{tabular}

Means in each column followed by different letters are significantly different $(\mathrm{P}<0.05)$ by Tukey test. 
The higher average daily gain of animals the fall (Table 6) is noteworthy, since in most of the rangelands from the south of Brazil, animal performance is reversed, i.e., it is better in the spring and summer. These results reveal a distinctive pastoral ecosystem, where, because of good rainfall regimes, optimal temperatures for temperate species, good light regime, satisfactory supply of soil nutrients for plant and high contribution of native winter species, make the fall a favorable period for forage quality. Floristic survey done in the fall showed expressive contribution of Piptochaetium stipoides and P. montevidense, Briza spp, Stipa setigera and Trifolium polimorphum. All these $\mathrm{C}_{3}$ species are starting growth in the fall and thus allowing young forage with high quality, enabling high individual weight gain.

However, the effect of compensatory weight gain of animals cannot be ruled out because during the summer the weight gain was significantly lower. According to Ryan (1990), compensatory growth is a growth rate above normal, sometimes observed after a period of nutritional restriction (in this case, during the summer), which has resulted in maintenance, reduction or even small gain weight and whose duration was sufficient to allow its adaptation to the lower nutritional status (in this case, 86 days). According to the same author, the severity and duration of the restriction are the main determinants of the rate of weight gain subsequent to the period of restriction.

Weight gain per area was obviously different in each season (Table 6). The lower weight gain in the summer can be explained by the low rainfall and high temperatures experienced during the months from December to February (Table 1$)$. The amount of forage mass in late spring ( $2156 \mathrm{~kg}$ $\mathrm{DM} / \mathrm{ha}$ - average among all treatments at the beginning of November) also may have contributed negatively to the animal performance during the summer. During the spring, cool season species begin to elongate their stem internodes and flower quickly. If there is not a sufficient severe grazing at this time, the vegetation gets excessive heights, decreasing the quantity/quality of light radiation in the lower strata due to shade (Nabinger, 1998). This competition for light precisely undermines the $\mathrm{C}_{4}$ species that are starting their growth in the lower strata and would be responsible for the quality of forage available at this time and throughout the summer.

The spring is also an important time to "shape" the structure of Andropogon lateralis, a species that is most frequent in the upper strata of the studied area. If this species is not heavily defoliated during October and November, the induction to flowering determines high proportion of elongated culms, hindering the access to the leaf strata. This change of sward structure determines its rejection and a decrease in the area effectively grazed. With the rejection of this species tolerant to drought and low temperature, the farmer will be losing their significant contribution to the forage availability effectively perceived by the animals in the other seasons (Aguinaga, 2004, Soares et al., 2005). The major difficulty in the management of rangelands in the Campanha region of Rio Grande do Sul is the transition between the spring and summer and the drought period that occurs between December and March. The low temperatures and frosts in the winter also exert negative effects on plant and animal, but these can be overcome with strategic deferrals, for example.

Live weight of the animals at the beginning of rearing was 230, 239 and $231 \mathrm{~kg}$ for natural, fertilized and improved pastures, respectively ( $\mathrm{P}>0.05)$. In May 2008, when the same animals were on average 18 months of age, the weight of steers in fertilized treatments (392 kg) was higher than that maintained in natural pasture $(357 \mathrm{~kg})(\mathrm{P}<0,10)$. The final weight of steers grazing in improved pasture reached an intermediate value $(363 \mathrm{~kg})$. The evolution of weight showed a similar growth trend between the different conditions of the pasture (Figure 2).

The changes in weight of animals kept on fertilized pasture, was virtually linear up to the beginning of summer. Furthermore, it was the only grassland condition where the steers did not lose weight between January and March (dry period).

The response in live weight gain per area observed at 302 days of evaluation did not differ significantly between the fertilized pasture (310.0 kg/ha) and improved pasture $(287.4 \mathrm{~kg} / \mathrm{ha})$, which were higher $(\mathrm{P}<0.05)$ than for the natural pasture (224 kg/ha), as expected due to greater forage production resulting from fertilization and winter over-seeded species. As a consequence, for the same forage offer, stocking rates were higher in these treatments, which, coupled with the GMD slightly higher although not

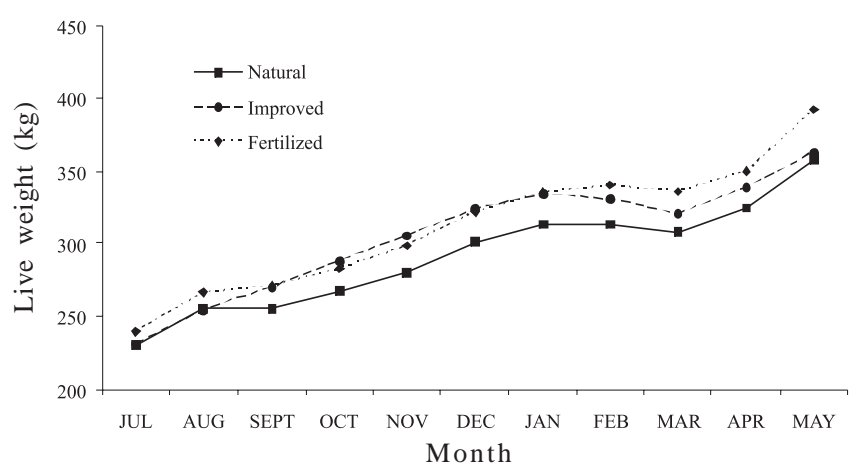

Figure 2 - Evolution of live weight of calves raised in natural, fertilized or improved pastures. 
significant, resulted in higher total weight gain per area. Similar effects were also found by Rizo et al. (2004). However, it is important to emphasize that the production of $224 \mathrm{~kg} / \mathrm{ha}$ obtained on natural grass in just 302 days of grazing is higher than the result obtained by Soares et al. (2005), who, in 325 days, produced $187 \mathrm{~kg} / \mathrm{ha}$ of PV. This result demonstrates the highest yield of natural grasslands in this region, allowing important animal performances without any input added.

In order to verify which features best explain the grazing animal performance, multiple regressions were performed to verify possible relationships between weight gain and the variables of the pasture. Among all the variables of the pasture selected to be included in the model, forage mass, forage content of dry matter, forage accumulation rate and canopy height were best related to weight gain of beef cattle during the rearing phase (Table 7 ).

The determination coefficient of 0.61 can be considered satisfactory, in view of the heterogeneous environment of natural pastures, where several biotic and biotic factors are interacting, raising difficulties at the prediction of animal performance. The fact that only four variables explain $61 \%$ of pasture ADG is an interesting result and shows the importance of measuring these parameters in pasture grazing trials.

It is observed that the highest amount of forage mass throughout the year was obtained in the pasture fertilized, which also caused greater weight gain. This same result was obtained with pasture height, where taller canopies allowed greater ADG. The opposite occurred for the dry matter content, i.e., the lower the DM content, the better the animal performance. This event may be illustrated with the smaller gains in the summer (Table 6), a period that had a higher dry matter content (Table 2). The accumulation rate, in turn, also influenced the weight gain from its higher or lower growth rate. Spring characterizes this effect as well, where the forage accumulation rate ( $\mathrm{kg} / \mathrm{ha} /$ day of DM) was 13.6 (natural grassland), 32.2 (fertilized) and 42.4 (improved) and ADG (kg/day BW) was 0.485 (natural grassland), 0.536 (fertilized) and 0.578 (improved).

Table 7 - Variables selected by the regression model - animal weight gain $\times$ characteristics of the pasture

\begin{tabular}{lccc}
\hline Pasture parameters & $\begin{array}{c}\text { parTial } \\
\mathrm{R}^{2}\end{array}$ & $\begin{array}{c}\mathrm{R}^{2} \text { from } \\
\text { the model }\end{array}$ & $\begin{array}{c}\mathrm{P} \\
\text { value }\end{array}$ \\
\hline Dry matter content (MS) & 0.22 & 0.22 & 0.01 \\
Total forage mass (TFM) & 0.29 & 0.50 & 0.01 \\
Forage accumulation rate (AR) & 0.06 & 0.57 & 0.04 \\
Canopy height (CH) & 0.04 & 0.61 & 0.07 \\
\hline Regression model: ADG $=1.857-0.0004$ TFM $-0.022 \mathrm{MS}-0.009 \mathrm{AR}+0.045 \mathrm{CH}$
\end{tabular}

In a way, the two variables dry matter content and forage accumulation rate indicate the contribution of green material in the forage. Almeida et al. (2000) also reported positive correlations between animal performance and availability of green biomass. According to Penning et al. (1991), the leaf area index and the mass of green leaves are the indices that best define the forage intake rate in winter pastures. In the same way, Euclides et al. (1999) claim that the voluntary consumption of dry matter is negatively correlated with the percentage of dead material and NDF content and a positive correlation is verified with total dry matter and dry matter of green leaves. Concerning the accumulation rate, Veiga et al. (1985) found good correlation between this variable sward and individual weight gain.

\section{Conclusions}

The native pasture on vertisols in the region of Campanha, in Rio Grande do Sul, when well managed in terms of forage allowance, provides high levels of forage production and animal performance, serving as an important forage resource for rearing beef cattle. The use of inputs such as fertilizers and over-seeding of winter forage species enables changes in certain characteristics of the pasture that are desirable for livestock production, including greater participation of green forage, increased sward height and greater forage production. The seasons have a marked influence on plant and animal productivity, determining the need for different management practices in each one. Grass height control can be used as a management tool in these pastures, because it shows good correlation with forage mass and is easy to perform and to be understood by the producer.

\section{Acknowledgements}

To CNPq and Fazenda do Cantagalo, for the financial support to the experiment.

\section{References}

AGUINAGA, J.A.Q. Dinâmica da oferta de forragem na produção animal e produção de forragem numa pastagem natural da Depressão Central do RS. 2004. 58f. Dissertação (Mestrado em Zootecnia) - Universidade Federal do Rio Grande do Sul, Porto Alegre.

ALMEIDA, E.X.; MARASCHIN, G.E.; HARTHMANN, D.E.L. et al. Oferta de forragem de capim-elefante anão "Mott" e o rendimento animal. Revista Brasileira de Zootecnia, v.29, n.5, p.1288-1295, 2000

BERETTA, V.; LOBATO, J.F.P.; MIELITZ NETTO, C.G. Produtividade e eficiência biológica de sistemas de produção de gado de corte de ciclo completo no Rio Grande de Sul. Revista Brasileira de Zootecnia, v.31, n.2, p.991-1001, 2002 . 
BERRETA, E.J. Ecophysiology and management response of the subtropical grasslands of southern south América. In: INTERNATIONAL GRASSLAND CONGRESS, 19., 2001, São Pedro. Proceedings... São Pedro: Sociedade Brasileira de Zootecnia, 2001. p.939-946.

CARASSAI, I.J.; NABINGER, C.; CARVALHO, P.C.F. et al. Recria de cordeiras em pastagem nativa melhorada submetida à fertilização nitrogenada: 1. Dinâmica da pastagem. Revista Brasileira de Zootecnia, v.37, n.8, p.1338-1346, 2008.

CARVALHO, P.C.F. A estrutura da pastagem e o comportamento ingestivo de ruminantes em pastejo. In: SIMPÓSIO SOBRE AVALIAÇÃO DE PASTAGENS COM ANIMAIS, 1., 1997, Maringá. Anais... Maringá: Universidade Estadual de Maringá, 1997. p.25-52.

CRANCIO, L.A.; CARVALHO, P.C.F.; NABINGER, C. et al. Ganho de peso de novilhas em pastagem nativa da Serra do Sudeste do RS submetida ao controle de plantas indesejáveis e intensidades de pastejo. Ciência Rural, v.36, n.4, p.1265-1271, 2006.

EMPRESA BRASILEIRA DE PESQUISA AGROPECUÁRIA EMBRAPA. Centro Nacional de Pesquisa do Solo CNPS. Sistema Brasileiro de Classificação de Solos. 2.ed. Rio de Janeiro: Embrapa Solos, 2006. 306p.

EUCLIDES, V.P.B.; THAIGO, L.R.L.; MARCELO, M.C.M. et al. Consumo voluntário de forragem de três cultivares de Panicum maximum sob pastejo. Revista Sociedade Brasileira de Zootecnia, v.28, n.6, p.1177-1185, 1999.

FONTOURA JÚNIOR, J.A.S.; QUADROS, F.L.F; MOOJEN, E.L. et al. Desempenho animal em pastagem natural com diferentes alternativas de introdução de espécies de estação fria. In : REUNIÃO DO GRUPO TÉCNICO EM FORRAGEIRAS DO CONE SUL - ZONA CAMPOS, 18., 2000, Guarapuava. Anais... Guarapuava: Universidade Federal do Paraná, 2000. p.149-150.

GATIBONI, L.C.; KAMINSKI, J.; PELLEGRINI, J.B.R. et al. Influência da adubação fosfatada e da introdução de espécies forrageiras de inverno na oferta de forragem de pastagem natural. Pesquisa Agropecuária Brasileira, v.35, n.8, p.1663-1668, 2000.

GONÇALVES, E.N.; CARVALHO, P.C.F.; KUNRATH, T.R. et al. Relações planta-animal em ambiente pastoril heterogêneo: processo de ingestão de forragem. Revista Brasileira de Zootecnia, v.38, n.9, p.1655-1662, 2009.

HAYDOCK, K.P.; SHAW, N.H. The comparative yield method for estimating dry matter yield of pasture. Australian Journal of Agriculture and Animal Husbandry, v.15, p.66-70, 1975.

KLINGMANN, D.L.; MILES, S.R.; MOTT, G.O. The cage method for determining consumption and yield of pasture forage. Journal of Society Agronomy, v.35, p.739-746, 1943.

LiTTELL, R.C.; MILLIKEN, G.A.; STROUP, W.W. et al. SAS system for mixed models. Cary: SAS Institute, 1996. 633p.

LOBATO, J.F.P.; BARCELLOS, J.O.J. Efeitos da utilização de pastagem melhorada no pós-parto e do desmame aos 100 ou 180 dias de idade no desempenho reprodutivo de vacas de corte. Revista Sociedade Brasileira de Zootecnia, v.21, n.3, p.385-395, 1992.
MARASCHIN, G.E. Production potential of South American grasslands. In: INTERNATIONAL GRASSLAND CONGRESS, 19., 2001, São Pedro. Proceedings... São Pedro: ESALQ, 2001. p.5-15.

MAZZANTI, A.; LEMAIRE, G.; GASTAL, F. The effect of nitrogen fertilization upon forage production of tall fescue sward continuously grazed with sheep. 1. Forage growth dinamics. Grass and Forage Science, v.49, n.2, p.111-120, 1994.

MOOJEN, E.L.; MARASCHIN, G.E. Potencial produtivo de uma pastagem nativa do Rio Grande do sul submetida a níveis de oferta de forragem. Ciência Rural, v.32, n.1, p.127-132, 2002.

MOTT, G.O.; LUCAS, H.L. The design, conduct and interpretation of grazing trials in cultivated and improved pastures. In: INTERNATIONAL GRASSLAND CONGRESS, 6., 1952, Pennsylvania. Proceedings... Pennsylvania: State College, 1952. p.1380-1385.

NABINGER, C. Princípios de manejo e produtivadade de pastagens. In:CICLO DE PALESTRAS EM PRODUÇÃO E MANEJO DE BOVINOS DE CORTE, 3., 1998, Canoas. Anais... Canoas: ULBRA, 1998. p.54-107.

NABINGER, C.; FERREIRA, E.T.; FREITAS, A.K. et al. Produção animal em campo nativo: aplicações de resultados de pesquisa. In: PILLAR, V.P.; MÜLLER, S.C.; CASTILHOS, Z.M.S. et al. (Org.). Campos sulinos: conservação e uso sustentável da biodiversidade. Brasília: Ministério do Meio Ambiente, 2009. p.175-198.

PENNING, P.D.; PARSONS, A.J.; ORR, R.J. et al. Intake and behavior responses by sheep to changes in sward characteristics under continuous stocking. Grass and Forage Science, v.46, n.1, p.15-28, 1991.

PÖTTER, B.A.A.; LOBATO, J.F.P. Efeitos de carga animal, pastagem melhorada e da idade de desmame no comportamento reprodutivo de vacas primíparas. Revista Brasileira de Zootecnia, v.33, n.1, p.192-202, 2004.

RISSO, E.J.; BERRETA, E.J.; LEVRATTO, J. et al. Efecto de la fertilización de N y P y la carga animal sobre la produtividad de uma Pastura Natural. In: SEMINÁRIO DE ACTUALIZACION EM TECNOLOGIAS PARA BASALTO, 1., 1998, Tacuarembo. Anais... Tacuarembó: INIA, 1998. p.147-152. (Serie Tecnica, 102).

RIZO, L.M.; MOOJEN, E.L.; QUADROS, F.L.F. et al. Desempenho de pastagem nativa e pastagem sobre-semeada com forrageiras hibernais com e sem glifosato. Ciência Rural, v.34, n.6, p.1921-1926, 2004.

RYAN, W.J. Compensatory growth in the cattle and sheep. Nutrition Abstracts and Reviews (Series B), v.6, n.9, p.653-664, 1990.

SANTOS, D.T.; CARVALHO, P.C.F.; NABINGER, C. et al. Eficiência bioeconômica da adubação de pastagem natural no sul do Brasil. Ciência Rural, v.38, p.437-444, 2008.

SOARES, A.B.; CARVALHO, P.C.F.; NABINGER, C. et al. A. Produção animal e de forragem em uma pastagem nativa submetida a distintas ofertas de forragem. Ciência Rural, v.35, n.5, p.1148-1154, 2005.

VEIGA, J.B.; MOTT, G.O.; RODRIGUES, L.R.A. et al. Capim elefante anão sob pastejo. 1 - Produção de forragem. Pesquisa Agropecuária Brasileira, v.20, n.8, p.929-936, 1985. 